\title{
Toward Sustainability Governance in Manufacturing Networks
}

\author{
Teuvo Uusitalo, Markku Reunanen, Katri Valkokari, Pasi Valkokari, \\ and Katariina Palomäki \\ VTT Technical Research Centre of Finland \\ Tekniikankatu 1, P.O. Box 1300, FIN-33101 Tampere, Finland \\ \{teuvo.uusitalo, markku.reunanen, katri.valkokari, \\ pasi.valkokari,katariina.palomaki\}@vtt.fi
}

\begin{abstract}
This paper presents a model for addressing sustainability governance in manufacturing networks. The model developed addresses sustainability governance within a manufacturing network as a process to guide the activities of all actors involved toward sustainable development and performance throughout the product life cycle. According to the model, there are three main tasks of sustainability governance: analysing, organising, and developing. These three main tasks are in accordance with company-level approaches but highlight the need for multilevel network governance.
\end{abstract}

Keywords: sustainability, governance, manufacturing networks.

\section{Introduction}

This paper deals with results of an on-going FP7-funded research project entitled 'Sustainable Value Creation in Manufacturing Networks' (SustainValue). The overall goal of the SustainValue project is to develop industrial models, solutions, and performance standards for new sustainable and better-performing production and service networks. One objective of the project is to develop a sustainability governance model for manufacturing networks. This paper presents the first results from the development of this model.

Corporate governance provides the structure through which the objectives of the company are set, and thus it forms the system by which an organisation makes and implements decisions in pursuit of its objectives [1]. The governance model defines 'what to do', 'how to do it', 'who should do it', and 'how it should be measured'. It addresses the rules, processes, metrics, and organisational structures needed for effective planning, decision-making, steering, and control [2]. The main differences between the company and network governance models are related to legal factors, decision-making processes, and control mechanisms. Companies are legal entities with their own goals, and their decision-making is based on internal hierarchical structures (control governance) whereas networks consist of independent actors, who have their own targets and decision-making models. 
The European Vision for 2020 report calls for understanding manufacturing as a network of complex and development-oriented relations. The new production paradigm is based on collaborative, value-adding networks, and globalisation has activated a different industrial revolution, leading to a new world distribution of production and markets [3]. Increasing demands for sustainability, however, have created new challenges and emerging opportunities for society and for business. A recent executive study illustrates that companies' perceptions of sustainability are changing. As in the past, company representatives see the potential for supporting corporate reputation. But recently they have also come to expect operational and growth-oriented benefits in cutting costs and pursuing opportunities provided by new markets and products. Additionally, in relation to the social and environmental aspects of sustainability, companies are now integrating sustainability principles into their business by retaining and motivating employees and by saving energy, alongside pursuit of other sustainability goals [4].

Since manufacturing activities at present are organised through networked processes, new models for network governance are needed for ensuring sustainable development and performance of manufacturing operations. These models should enable clear identification of those network actors and stakeholders who influence and can be influenced by the sustainability of the product in the course of its life cycle.

\section{Value}

Sustainability is often perceived from a limited value creation view. The focus has been on an economic, compliance, regulation or legislation perspective, hence raising the need for a more holistic view of sustainable value that integrates economic, social and environmental goals. From a network perspective, the scope of value needs to go beyond customers, immediate partners and shareholders. The scope should consider relationships, exchanges and interactions. Value can be defined as the set of benefits derived by a stakeholder from an exchange. This implies the need for improved understanding of stakeholder value, and the need to seek opportunities for alignment and exchanges between stakeholders. [5]

The development of a common value system in a network context is important in order to support the sustainability of collaborative behaviour [6]. Different value systems of network partners can lead to different perceptions of benefits and noncollaborative behaviours. In order to overcome this, mechanisms to promote transparency and alignment of value systems could be introduced at the level of the governance rules. Research is needed to identify suitable indicators of the collaboration level of each partner. [7]

The key to new sustainable business models is in understanding the value from network perspective. A value network generates value through complex dynamic exchanges between enterprises, customers, suppliers, partners, stakeholders and the community. These networks engage in transactions around goods, services, and revenue. In addition the two other aspects are knowledge value and intangible value or benefits. All three are important in a value network. [8] 


\section{Manufacturing Networks}

In traditional manufacturing network operations of suppliers, lead producers (such as OEMs) and customers are seen as independent sequential tasks, which form a value chain. Since the 1990s, however, this pattern has been changing and the theoretical discussion has emphasised the transfer from value chains to value networks $[9,10]$.

The trend among customers, lead producers (OEMs), and suppliers seems to be to engage in forward transfer in their value chains. This means that customers, lead producers or OEMs outsource manufacturing (give up earlier value chain phases), and their suppliers try to increase services (add later value chain phases and give up some of the earlier phases). Interdependency of operations and co-creation between the actors have been emphasized from several theoretical viewpoints $[11,12,13]$.

In the new network economy, the success of a firm depends on its strategic collaboration with other organizations that have an influence on the creation and delivery of its services or products. Manufacturing networks can, therefore, be defined as 'not only a new type of manufacturing system deriving new strategic capabilities and requiring design tools but also posing new theoretical questions about systems and decision processes' [14].

Fjeldstad and Stabell presented a value configuration framework in which value network and value shop are the two alternatives to Michael Porter's traditional concept of value chains [15]. Later on, based on the notion of the value creation framework, Möller et al. have suggested a value continuum framework that includes three generic net types that are current business nets, business renewal nets, and emerging new business nets [16]. Current business nets are value systems with a high level of determination and well-known and well-specified patterns of activities and resources. Emerging new business nets are characterized by radical changes and inherent uncertainty. In between these polar opposites are business renewal nets, which produce incremental local changes in existing value systems. Practical approaches in manufacturing networks can also be characterised by applying three network types. First, the traditional supply networks have the focus on efficiency of processes - the roles and connections between actors are quite well defined. Secondly, in business enhancing networks the focus changes from physical components to competences, while actors try to solve customer's problems together. Thirdly, emergence of radically new business opportunities requires new connections and network members - often over industry sectors. The business models of network actors differ within these network types. Furthermore, each business network evolves over time as network roles, business models, as well as strategies of actors change. Table 1 compares the key characteristics of these value creation frameworks and illustrates their appearance in manufacturing network practises. 
Table 1. Value creation approaches in manufacturing networks

\begin{tabular}{|l|l|l|l|}
\hline Approach & \multicolumn{3}{|l|}{ Value network types and their key characteristics } \\
\hline $\begin{array}{l}\text { Value configuration } \\
{[13]}\end{array}$ & $\begin{array}{l}\text { Value chain } \\
\text { (components as } \\
\text { value element) }\end{array}$ & $\begin{array}{l}\text { Value shop (value } \\
\text { based on } \\
\text { competences) }\end{array}$ & $\begin{array}{l}\text { Value network } \\
\text { (connections as } \\
\text { value elements) }\end{array}$ \\
\hline $\begin{array}{l}\text { Value continuum } \\
{[14]}\end{array}$ & $\begin{array}{l}\text { Current business } \\
\text { nets (efficiency } \\
\text { of operations) }\end{array}$ & $\begin{array}{l}\text { Business renewal } \\
\text { nets (incremental } \\
\text { changes) }\end{array}$ & $\begin{array}{l}\text { Emerging new } \\
\text { business nets } \\
\text { (radical changes } \\
\text { and uncertainty) }\end{array}$ \\
\hline $\begin{array}{l}\text { Practical approaches } \\
\text { in manufacturing } \\
\text { networks }\end{array}$ & $\begin{array}{l}\text { Traditional } \\
\text { supply networks }\end{array}$ & $\begin{array}{l}\text { Business enhancing } \\
\text { networks, like } \\
\text { service networks }\end{array}$ & $\begin{array}{l}\text { Innovation } \\
\text { networks }\end{array}$ \\
\hline
\end{tabular}

In manufacturing industries value network consist of organizations co-operating with each other to benefit all network members. Lead producer and its suppliers and customers form a typical value network. Value system consists of the suppliers' value networks (who provide input), core company's value network (that produces products), the distributers' and retailer's value networks (who distribute products to customers) and the customers' value networks (who use the products in their own activities) [17].

The focus should be broadened from supplier-lead producer-customer relationships to collaborative relationships [18]. Furthermore, based on system thinking the concept of business ecosystems has been introduced to highlight the importance of a value system, where all stakeholders co-produce value and thereby, value from co-operation is also captured by all stakeholders [19]. In addition to the main actors of a value network (lead producers, their suppliers and customers) also interests of other involved actors (external stakeholders) should be considered. The need to consider sustainability requires tighter collaboration among a wide range of stakeholders. Collaborative networks is one concept that can bring a significant contribution to the better understanding of the stakes and paths towards potential solutions in sustainability. Studies on trust management, value systems, multicultural and multilegal contexts for collaborative networks can help in the development of better governance methods for sustainable development [20].

\section{Network Governance Models in Manufacturing}

From the standpoint of organisation theory, there are three main governance models: hierarchies (e.g., firms), markets, and networks. Networks are a hybrid model between hierarchies and markets, possessing characteristics from both extremes. Network organisation and management include governance structures that have to do with the degree of central or distributed co-ordination [21].

On the basis of their structure, networks can be divided into hierarchical hub-spoke and multiplex models [22]. In the hub-spoke model, the central actor (i.e., lead producer 
or OEM) is responsible for the network governance. In contrast, network governance in the multiplex model takes place within and between the network actors. Three distinct types of governance within networks can be identified: i) shared governance, ii) lead-organisation-governed, and iii) network-administrative-organisation-governed [23]. In NAO governance, all activities and decisions are co-ordinated through one organisation specifically created to oversee the network.

Governance structures are what bring actors into working together - the process, rules, and norms by which the network enables participating organisations to influence the network's operations and decision-making. Governance mechanisms can be divided into contractual-based and relational-based governance [24]. Contractual governance emphasises the use of a formalised, legally binding agreement to govern the inter-firm relationship. Relational governance, in contrast, highlights the role of norms of solidarity, flexibility, and information-sharing in the relationship process.

Since networks are mostly composed of autonomous organisations and are not legal entities, the network's participants typically have limited formal accountability for network-level goals, and conformance with rules and procedures is not governed by binding regulations but is voluntary. For goal-directed organisational networks with a distinct identity, governance is still necessary for ensuring that participants engage in collective and mutually supportive action, that conflict is addressed, and that network resources are acquired and utilised efficiently and effectively. Governance involves use of institutions and structures of authority and collaboration to allocate resources and to co-ordinate and control joint action across the network as a whole [25].

\section{$5 \quad$ Model for Sustainability Governance in Manufacturing Networks}

The present - and especially the future challenge - is to govern sustainability within manufacturing networks and broader business ecosystems. The process towards developing a sustainable manufacturing value network requires reassessing value creation and capturing from the start of a business. Moreover, a more holistic sustainable business model of manufacturing networks should include economic, environmental and social impacts of the business.

The governance model developed illustrates sustainability governance within a manufacturing network as a process for guiding the activities of all actors involved toward sustainable development and performance over a product's life cycle. There are three main tasks of sustainability governance: analysing, organising, and developing as illustrated in the Fig. 1. Through these, the governance model illustrates a process that integrates i) requirements and commitments of stakeholders within the manufacturing network as well as ii) business models and the self-interest of manufacturing-network companies. 


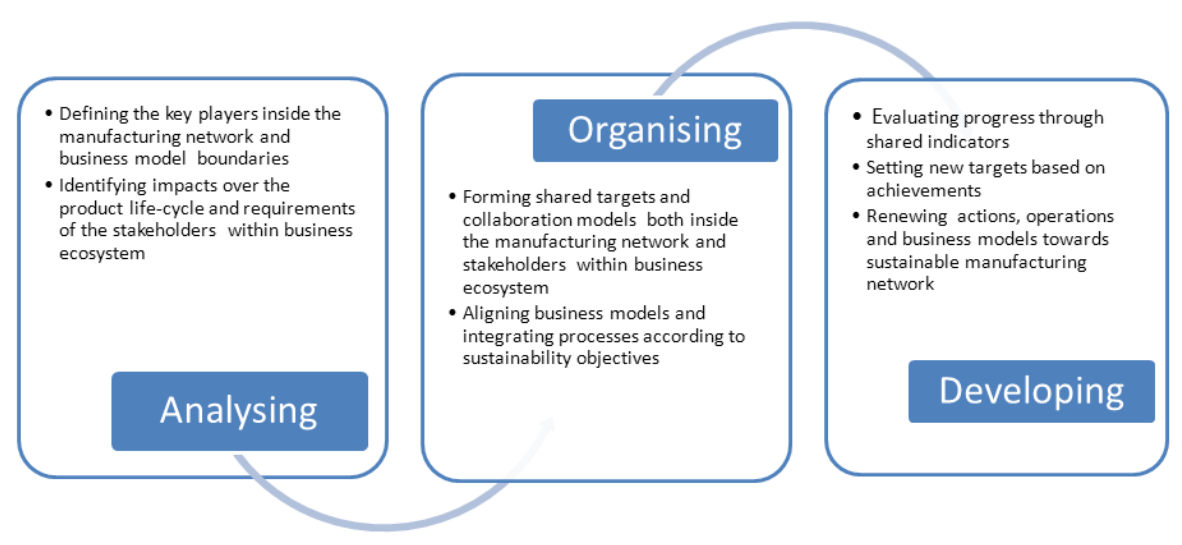

Fig. 1. Model for sustainability governance in manufacturing networks

To guide the activities of all actors involved toward the sustainability objectives, companies must first determine the key players in the manufacturing network and the boundaries of the business model. Therefore, the network analysis requires visualisation of the connections (business relationships, ownership, etc.) between the actors. In this phase, an important aspect of the sustainability governance in manufacturing networks is the connection between sustainable development and business models. In order for the network-members to understand the network's value for each member, the objectives, interests, and expectations of each should be covered. Consequently, it is important to assess the requirements and expectations of the stakeholders within the business ecosystem. On the basis of these analyses, companies would be able to identify sustainability impacts over the product life cycle and the requirements imposed for the actors involved.

The analyses of said actors, their requirements, and the total impact direct the organising and management of the sustainability development at network level. Shared targets and collaboration models are formed both inside the manufacturing network and with respect to other stakeholders within the business ecosystem. Alignment of business models and integration of processes in accordance with the sustainability objectives should be carefully considered. Different collaboration models are required for different situations; e.g., the sustainability objectives should be considered when one is deciding with whom to collaborate and how.

In order to ensure continuous improvement as well as renewal, progress should be evaluated via shared indicators and new targets should be set transparently, based on the achievements. Actors will be able to renew actions, operations, and business models together in pursuit of sustainability goals.

\section{Conclusions}

The model developed addresses sustainability governance within a manufacturing network as a process to guide the activities of all actors involved toward sustainable 
development and performance throughout the product life cycle. According to the model, there are three main tasks of sustainability governance: analysing, organising, and developing. These three main tasks are in accordance with company-level approaches but highlight the need for multilevel network governance.

One of the requirements identified in this study is that sustainability should be integrated into companies' as well as networks' core strategies. The governance model plays an important role for this aim and can be utilised for supporting the alignment of business models and processes with sustainability objectives.

A practical implication of the developed model is that it supports management in analysis and decision-making related to strategic collaboration for sustainability. The model contribution to scientific community is that it supports identification of governance mechanisms related to shared value system in downstream - upstream networking.

The model presented in this paper will be further refined as the SustainValue project progresses. The next version will take into account the advances made in the research carried out in the project. This includes, for example, how governance, corporate norms and values, and ownership structure drive sustainability within the business model and architecture. The model will be further developed and piloted together with companies in order to link it to new methods and tools that will be developed in the SustainValue project as well as to existing methods such as Global Reporting Initiative (GRI).

Acknowledgements. The research leading to these results has received funding from the European Community's Seventh Framework Programme (FP7, 2007-2013) under grant agreement 262931. The authors wish to acknowledge the European Commission for their support.

\section{References}

1. ISO 26000:2010: Guidance on social responsibility. International Organization for Standardization (2010)

2. Gewald, H., Helbig, K.: A governance model for managing outsourcing partnership: A view from practice. In: Proceedings of the 39th Hawaii International Conference on System Sciences, HICSS 2006 (2006)

3. European Commission: MANUFUTURE - a vision for 2020: Assuring the future of manufacturing in Europe. Office for Official Publications of the European Communities, Luxembourg (2004)

4. Bonini, S.: The business of sustainability. McKinsey Global Survey results. McKinsey \& Company (2011)

5. Evans, S., Rana, P., Short, S.: D2.1 - State-of-practice in business modelling and valuenetworks, emphasising potential future models that could deliver sustainable value (2012), http://www.sustainvalue.eu/publications/D2_1_Final_Rev1_0_we b.pdf (last accessed June 20, 2012)

6. Camarinha-Matos, L.M., Macedo, P.: A conceptual model of value systems in collaborative networks. Journal of Intelligent Manufacturing 21(3), 287-299 (2010) 
7. Abreu, A., Camarinha-Matos, L.M.: On the role of value systems to promote the sustainability of collaborative networks. International Journal of Production Research 46(5), 1207-1229 (2008)

8. Allee, V.: Reconfiguring the Value Network. Journal of Business Strategy 21(4), 36-39 (2000)

9. Normann, R., Ramirez, R.: Designing Interactive Strategy: From the Value Chain to the Value Constellation. John Wiley \& Sons, Chichester (1994)

10. Peppard, J., Rylander, A.: From Value Chain to Value Network: Insights for Mobile Operators. European Management Journal 24(2-3), 128-141 (2006)

11. von Hippel, E.: Democratizing Innovation. The MIT Press, Cambridge (2005)

12. Dyer, J.H.: Collaborative advantage: winning through extended enterprise supplier networks. Oxford University Press, Oxford (2000)

13. Chesbrough, H.: Open innovation. Harvard Business School Press, Boston (2003)

14. Shi, Y., Gregory, M.: International Manufacturing Networks - to develop global competitive capabilities. Journal of Operation Management 16(2-3), 195-214 (1998)

15. Fjeldstad, Ø.D., Stabell, C.B.: Configuring Value for Competitive Advantage: On Chains, Shops, and Networks. Strategic Management Journal 19(5), 413-437 (1998)

16. Möller, K., Rajala, A., Svahn, S.: Strategic business nets - their type and management. Journal of Business Research 58(9), 1274-1284 (2005)

17. Miltenburg, J.: Manufacturing Strategy - How to Formulate and Implement a Winning Plan. Productivity Press, New York (2005)

18. Vallet-Bellmunt, T., Martínez-Fernández, M.T., Capó-Vicedo, J.: Supply chain management: A multidisciplinary content analysis of vertical relations between companies, 1997-2006. Industrial Marketing Management 40(8), 1347-1367 (2011)

19. Moore, J.F.: The Death of Competition: Leadership \& Strategy in the Age of Business Ecosystems. Harper Business, New York (1996)

20. Camarinha-Matos, L.M., Afsarmanesh, H., Boucher, X.: The role of collaborative networks in sustainability. In: Camarinha-Matos, L.M., Boucher, X., Afsarmanesh, H. (eds.) PRO-VE 2010. IFIP AICT, vol. 336, pp. 1-16. Springer, Heidelberg (2010)

21. Valkokari, K., Valkokari, P., Reunanen, M., Palomäki, K., Amirmostofian, A.: D1.2 Towards sustainability governance in manufacturing networks (2012), http://www.sustainvalue.eu/publications/D1_2_final_Rev1_0_we b.pdf (last accessed June 20, 2012)

22. Svahn, S., Westerlund, M.: The modes of supply net management: A capability view. Supply Chain Management: An International Journal 12(5), 369-376 (2007)

23. Doz, Y.: Clubs, Clans and Caravans: The Dynamics of Alliance Memberships and Governance. Carnegie Bosch Institute, Berlin (2001)

24. Provan, K.G., Fish, A., Sydow, J.: Interorganizational networks at the network level: A review of the empirical literature on whole networks. Journal of Management 33(3), 479-516 (2007)

25. Poppo, L., Zenger, T.: Do formal contracts and relational governance function as substitutes or complements? Strategic Management Journal 23(8), 707-725 (2002)

26. Provan, K.G., Kenis, P.: Modes of network governance: Structure, management, and effectiveness. Journal of Public Administration Research and Theory 18(2), 229-252 (2008) 